\title{
A new mouse model of junctional epidermolysis bullosa: the LAMB3 628G $>$ A knockin mouse
}

\author{
Johanna Hammersen ${ }^{1 *}$, Jin Hou', Stephanie Wünsche', Sven Brenner ${ }^{2}$, Thomas Winkler ${ }^{2}$, Holm Schneider $^{1}$ \\ From 50th Workshop for Pediatric Research \\ Gottingen, Germany. 20-21 March 2014
}

Junctional epidermolysis bullosa (JEB) is a group of recessively inherited genodermatoses, characterized by tissue separation in the epidermal basement membrane due to defective anchoring proteins. The lethal Herlitz type of this disorder is caused by absence of laminin332. Affected individuals suffer from widespread erosions of skin and mucous membranes and very often die within the first year of life. Mouse models lacking the $\alpha 3$ - or $\gamma 2$-chain of laminin-332 have been developed and a spontaneous 33 -knockout mouse exists, but all die shortly after birth. We generated a new mouse model of JEB by knockin of the point mutation $628 \mathrm{G}>\mathrm{A}$ (p.E210K) in the gene encoding the laminin-332 ß3chain, $L A M B 3$. In compound heterozygous humans, this mutation has always been associated with lifelong skin blistering without reduced life expectancy.

Fourteen homozygous $L A M B 3628 \mathrm{G}>\mathrm{A}$ knockin mice were analyzed. Most of them showed skin blistering with tissue separation in the basement membrane soon after birth. Laminin-332 was almost completely absent. None of the homozygous LAMB3 628G>A knockin mice survived longer than 72 hours. LAMB3 gene expression levels in heterozygous and homozygous $L A M B 3$ 628G>A knockin mice, however, were similar to wild-type mice. Analysis of the $L A M B 3$ transcript revealed alternative splicing in homozygous $L A M B 3$ 628G $>$ A knockin mice: a 64 base-pair deletion of exon 7 led to a frame-shift and a premature termination codon. Due to alternative splicing, the phenotype of this new mouse model resembles that of knockout mice. The $L A M B 3$ 628G>A knockin mouse may contribute to a better understanding of the molecular basis of JEB.

'Department of Pediatrics and Adolescent Medicine, University Hospital Erlangen, Erlangen, Germany

Full list of author information is available at the end of the article
Authors' details

'Department of Pediatrics and Adolescent Medicine, University Hospital Erlangen, Erlangen, Germany. ${ }^{2}$ Department of Biology, Nikolaus-FiebigerCenter for Molecular Medicine, Friedrich-Alexander-University ErlangenNürnberg, Erlangen, Germany.

Published: 11 September 2014

doi:10.1186/2194-7791-1-S1-A12

Cite this article as: Hammersen et al: A new mouse model of junctional epidermolysis bullosa: the LAMB3 628G>A knockin mouse. Molecular and Cellular Pediatrics 2014 1(Suppl 1):A12.

\section{SpringerOpen ${ }^{\odot}$}

(C) 2014 Hammersen et al; licensee Springer This is an Open Access article distributed under the terms of the Creative Commons Attribution License (http://creativecommons.org/licenses/by/2.0), which permits unrestricted use, distribution, and reproduction in any medium, provided the original work is properly cited.
Submit your manuscript to a SpringerOpen ${ }^{\circ}$ journal and benefit from:

- Convenient online submission

- Rigorous peer review

- Immediate publication on acceptance

- Open access: articles freely available online

- High visibility within the field

- Retaining the copyright to your article

Submit your next manuscript at $>$ springeropen.com 